\title{
Karyotype, C-band and NOR phenotype of Anatolian endemic fish Squalius anatolicus (Bogutskaya, 1997) (Teleostei, Leuciscidae)
}

\section{Anadolu'ya endemik Squalius anatolicus (Bogutskaya, 1997) (Teleostei, Leuciscidae) türünün karyotip, C-bant ve NOR fenotipi}

\author{
Sevgi Ünal Karakuş ${ }^{1 *}$ • Muhammet Gaffaroğlu² \\ ${ }^{1}$ Department of Molecular Biology and Genetics, Faculty of Science, Bartın University, 74100 Bartın, Turkey \\ 2 Department of Molecular Biology and Genetics, Faculty of Science and Art, Kırşehir Ahi Evran University, \\ 40100 Kırşehir, Turkey
}

Abstract: The karyotype and distribution of constitutive heterochromatin and nucleolus organizer regions (NORs) of Anatolian leuciscine endemic to Lake Beysehir, Squalius anatolicus (Bogutskaya, 1997) were analyzed respectively using conventional Giemsa-staining, C-banding and Ag-impregnation. Diploid chromosome number was $2 n=50$ and karyotype consisted of 7 pairs of metacentric, 13 pairs of submetacentric, 5 pairs of subtelo- to acrocentric chromosomes, NF value equaled 90 . Heteromorphic elements indicating sex chromosomes were not detected. C-banding revealed clear pericentromeric constitutive heterochromatin blocks in several chromosomes. Ag-impregnation revealed the size heteromorphism of NORs that covered almost the entire short arms of the middle-sized submetacentric chromosome pair. The karyotype pattern and simple NOR phenotype of $S$. anatolicus are nearly identical with that found not only in Squalius species analyzed to date but also in many other representatives of the Eurasian leuciscine cyprinids, which indicates remarkable chromosome stasis in this leuciscid lineage.

Keywords: Leuciscid cytotaxonomy, fish cytogenetics, chromosome banding, major rDNA sites, Squalius anatolicus

Öz: Beyşehir Gölü'ne endemik Anadolu leuciscini Squalius anatolicus (Bogutskaya, 1997)'un karyotipi, konstitütif heterokromatin dağılımı ve çekirdekçik organize edici bölgeleri (NOR'lar) sırası ile geleneksel Giemsa-boyama, C-bantlama ve Gümüs emdirme teknikleri kullanılarak analiz edilmiştir. Diploid kromozom sayısı $2 n=50$ olmak üzere; karyotipinin 7 çift metasentrik, 13 çift submetasentrik, 5 çift subtelo - akrosentrik kromozomdan oluştuğu ve toplam kol sayısının 90 olduğu tespit edilmiştir. Cinsiyet kromozomlarını temsil eden heteromorfik yapılar gözlenmemiştir. C-bantlama birçok kromozomda belirgin perisentromerik heterokromatin blokları ortaya cıkarmıştır. Gümüs emdirme ile orta boy submetasentrik kromozom çiftinin neredeyse kısa kolunun tamamını kaplayan NOR'ların büyüklük heteromorfizmi tespit edilmiştir. S. anatolicus'un karyotip şekli ve temel NOR fenotipi sadece bugüne kadar analiz edilen Squalius türlerinde değil, aynı zamanda bu leuciscid soyunda büyük ölçüde kromozom durumunu gösteren Avrasya leuciscinlerinin diğer birçok temsilcisinde bulunanla hemen hemen aynıdır.

Anahtar kelimeler: Leuciscid sitotaksonomisi, balık sitogenetiği, kromozom bantlama, major rDNA bölgeleri, Squalius anatolicus

\section{INTRODUCTION}

The genus Squalius was recognized within the genus Leuciscus for a long time until morphological and molecular data demonstrated that Leuciscus represents another leuciscine lineage (Zardoya and Doadrio, 1999). The Squalius genus belongs to the Leuciscinae subfamily and comprises at least 45 species that are commonly named chub (Özulug and Freyhof, 2011). The genus represented by 22 species includes Squalius adanensis, $S$. anatolicus, $S$. aristotelis, $S$. berak, $S$. cappadocicus, $S$. carinus, $S$. cephaloides, $S$. cephalus, S. cii, S. fellowesii, S. irideus, S. kosswigi, $S$. kottelati, S. lepidus, S. orientalis, S. orpheus, S. pursakensis, S. recurvirostris, S. semae, S. seyhanensis, S. spurius, and S. turcicus in Anatolia (Çiçek et al., 2020).

Squalius species are present in almost every water body in Anatolia (Stoumboudi et al., 2006) while only a few populations have been defined in sufficient detail in Anatolia and adjacent basins. Some species of Squalius were reported from the Tigris, the Euphrates, the Orontes and the Beysehir drainages, respectively. Bogutskaya (1997) identified populations of Lake Beysehir basin as $S$. anatolicus (known as Beysehir dace) (Turan et al., 2009). This species has restricted distribution in central Anatolia, but it exists also in the Manavgat River, draining to the Mediterranean east of Antalya. The current population trend is reported as decreasing and it was known as endangered until 2006 (Özulug and Freyhof, 2011) but recently it is listed as the least concern in the IUCN Red List (Freyhof, 2014).

The subfamily Leuciscinae includes virtually 70 freshwater genera nonetheless approximately 25 leuciscine genera have been cytogenetically investigated (Rab and Collares-Pereira, 1995; Bianco et al., 2004; Rossi et al., 2012). The primary challenge in leuciscines' cytogenetic analysis relevant in 
effectively descrying species at the karyotype level, fundamental for advanced chromosomal studies (Pereira et al., 2013). In earlier studies, S. anatolicus was described as morphologically and analysed as parasitologically (Turan et al., 2013; Aydogdu et al., 2015) while there are no cytogenetic data reported. The aim of the study is to investigate the karyotype, distribution of constitutive heterochromatin and NORs' phenotype that it means number and position of major rDNA/NOR sites of Anatolian leuciscine endemic to Beysehir Lake, S. anatolicus (Bogutskaya, 1997) using conventional Giemsa-staining, C-banding, and Ag-impregnation.

\section{MATERIAL AND METHODS}

Eight adult individuals of $S$. anatolicus (four females and four males) were collected from Lake Beyşehir basin, Konya, Turkey $\left(37^{\circ} 52^{\prime} \mathrm{N}, 31^{\circ} 35^{\prime} \mathrm{E}\right)$ using electrofishing. The alive individuals were transported to the laboratory and kept in a well-aerated aquarium until analysis. The specimens were deposited in a fish collection of the Genetic Research Laboratory of Kırşehir Ahi Evran University, Kırşehir, Turkey.

The chromosome preparations were obtained according to standard protocol of Collares-Pereira (1992), using direct air drying technique. The slides were stained with $4 \%$ Giemsa staining solution (with Sorenson's phosphate buffer, $\mathrm{pH}$ 6.8). The metaphase plates were examined and photographed using Leica DMLB. The total sum of metaphases was 411 and metaphase number was not evenly ratio for per each of eight analysed specimens. The C-bands were obtained according to Sumner (1972). The Ag-impregnation method of Howell and Black (1980) was applied to determine NORs. The chromosomes were classified using a modified version of Levan et al. (1964), and the fundamental arm number (NF) was identified by scoring the metacentric $(m)$ and submetacentric (sm) as biarmed and subtelo-acrocentric (st/a) chromosomes as uniarmed chromosomes.

\section{Ethical Statement}

Permissions of sampling and laboratory study on fish have issued by respectively the Republic of Turkey Ministry of Agriculture and Forestry (the number and date of fieldwork permission: B.12.0.KKG.0.17/106.01-11-01/3007840-02.02.2010), and the Kırşehir Ahi Evran University Animal Experiments Local Ethics Committee (the number and date of fieldwork permission: 68429034/02-14.02.2019).

\section{RESULTS}

All analyzed $S$. anatolicus specimens showed $2 n=50$ chromosomes. Karyotype consisted of 7 pairs of $m, 13$ pairs of sm, 5 pairs of st/a chromosomes (Table 1). The fundamental number of chromosome arms equaled NF $=90$ (Figure 1). The morphologically differentiated sex chromosomes were not detected.
Table 1. Cytogenetic data of Squalius anatolicus

\begin{tabular}{lcccccccc}
\hline Species & $\begin{array}{c}\text { Specimen Metaphase } \\
\text { number number }\end{array}$ & $2 n$ & NF & & \multicolumn{2}{c}{$\begin{array}{c}\text { Chromosome } \\
\text { morphology }\end{array}$} \\
\hline Squalius anatolicus & 8 & 411 & 50 & 90 & 14 & 26 & 10 \\
\hline
\end{tabular}

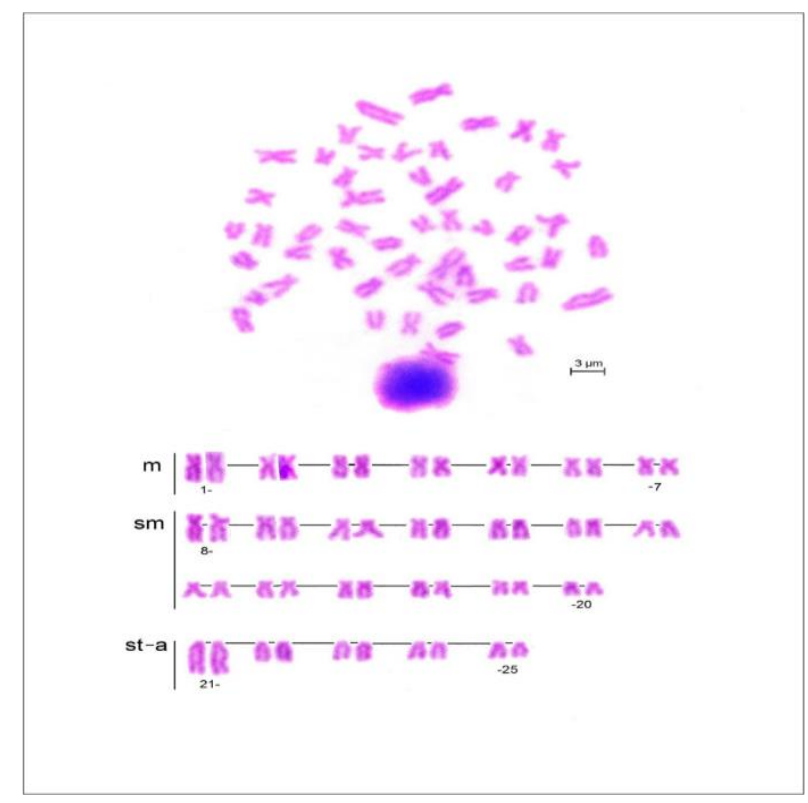

Figure 1. Giemsa stained metaphase and corresponding karyotype of Squalius anatolicus. Scale bar $=3 \mu \mathrm{m}$

C-banding procedure showed blocks of constitutive heterochromatin $(\mathrm{CH})$ mostly in (peri) centromeric regions of several chromosomes. However, intercalar or terminal Cbands were also visible on some chromosomes (Figure 2).

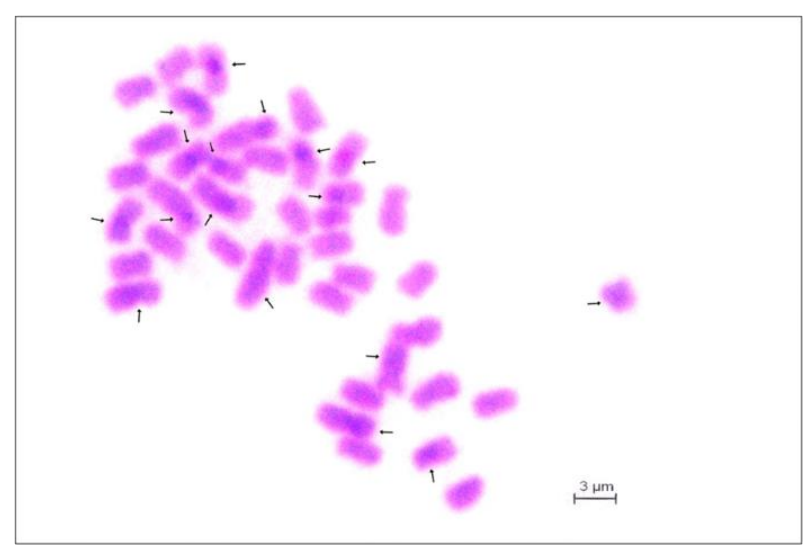

Figure 2. Metaphase chromosomes of $S$. anatolicus after Cbanding. Arrows indicate C-bands. Scale bar $=3$ $\mu \mathrm{m}$

The NORs were located terminally on short arms of one sm chromosome pair (Figure 3). Besides, the size heteromorphism of NORs in the homologous chromosomes were identified by Ag-impregnation. NORs covered almost the 
entire short arms of one pair of the homologous chromosomes, while the others were identified to be more restricted to the end of the short arm.

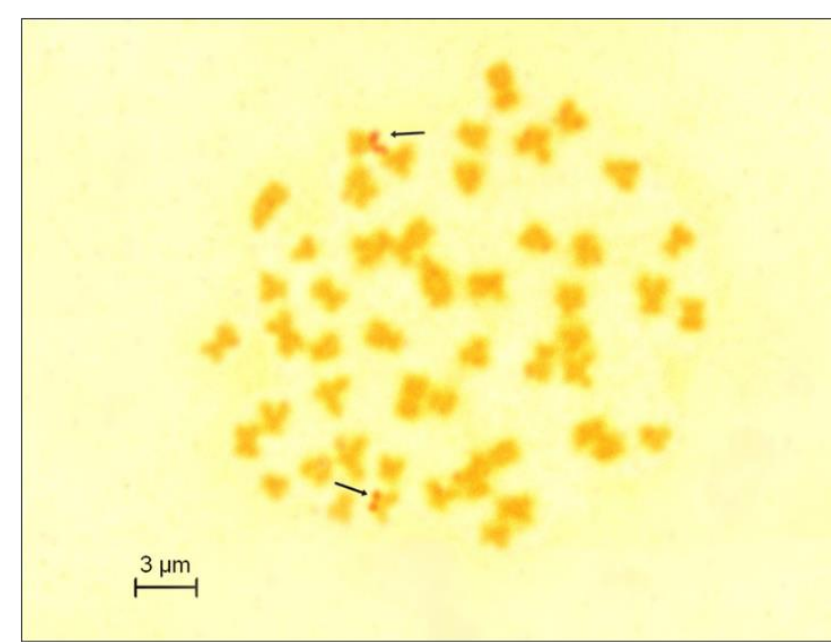

Figure 3. Metaphase chromosomes of $\mathrm{S}$. anatolicus after $\mathrm{Ag}$ impregnation. Arrows indicate NORs. Scale bar $=3$ $\mu \mathrm{m}$

\section{DISCUSSION}

Bogutskaya (1997) previously recognized that the Squalius population in Lake Beyşehir is a different species from $S$. cephalus, and it was identified as endemic species $S$. anatolicus.

The karyotype and chromosomal characteristics of $S$. anatolicus were analyzed in this study for the first time. The diploid chromosome number was $2 n=50$ and NF was 90 . Within the individuals examined no karyotype variation was identified among the individuals and their sex. Acrocentric chromosomes were represented by 5 pairs of chromosomes, while the sm chromosomes were represented by 13 pairs, being thus the prevalent morphological chromosome type within the karyotype.

Rab and Collares-Pereira (1995) reported that the diploid chromosome numbers within leuciscins are usually $2 n=(48)$ 50 (52) and that their karyotype macrostructure is composed of 6 to 8 pairs of $\mathrm{m}, 12$ to 14 pairs of sm, and 2 to 4 pairs of st/t chromosomes. Amemiya and Gold (1990), on the other hand, observed that while $90 \%$ of North American cyprinids had a karyotype morphology of $2 n=50$, this $2 n$ could vary from 48 to 52 , and that the NF value could vary from 80 to 100. In terms of $2 n$ and karyotype macrostructure, results from the present study are in line with above mentioned reports.

Cytogenetic studies of this leuciscine lineage demonstrated that Squalius carolitertii (Syn: Leuciscus carolitertii) has $2 n=50$ and karyotype with 6 pairs of $m, 15$ pairs of st, and 4 pairs of a chromosomes, $S$. pyrenaicus (Syn: Leuciscus pyrenaicus) $2 n=50$ and karyotype with 6 pairs of $\mathrm{m}, 16$ pairs of sm, and 3 pairs of a chromosomes (while the morphology of the chromosomes of $S$. carolitertii is stable, karyotype of $S$. pyrenacius is variable) (CollaresPereira et al., 1998) (Table 2). Recent cytogenetic analysis of S. carinus, S. fellowesii (Karasu Ayata, 2020) and S. seyhanensis (Unal and Gaffaroğlu, 2016) have shown the same $2 n$ as in other Squalius and Leuciscus species and karyotypes consisted of 12 pairs of $m, 10$ pairs of sm and 3 pairs of st/a chromosomes (NF $=94) ; 10$ pairs of $m, 10$ pairs of $\mathrm{sm}$ and 5 pairs of st/ chromosomes (NF $=90) ; 8$ pairs of $\mathrm{m}$, 14 pairs of sm and 3 pairs of st/a chromosomes (NF $=94$ ) respectively. Boron et al. (2009) shown that $L$. idus has $2 n=$ 50 and NF $=86$, and karyotype with 5 pairs of $m, 13$ pairs of sm, 3 pairs of st and 4 pairs of a chromosomes and $L$. leuciscus has $2 n=50$ and NF $=86$, karyotype with 6 pairs of m, 12 pairs sm, 4 pairs of st and 3 pairs of a chromosomes. The same study (Boron et al., 2009) have also indicated that L. leuciscus (Syn: Leuciscus leuciscus baicalensis kirgisorum), L. schmidti and $L$. bergi have $2 n=50$ and NF = 90 , and karyotype with 9 pairs of $m, 11$ pairs of sm and 5 pairs a chromosomes (Mazik et al., 1986). In all the previously analyzed species of Leuciscus, the number of $\mathrm{m}$ chromosomes, in $L$. leuciscus and $L$. idus the number of sm chromosomes higher and, the NF similar to the present study. In terms of NF, results presented in this study are in agreement with above mentioned studies. On the other hand, cytogenetic data of $S$. cephalus (Syn: Leuciscus cephalus) vary from one study to another. Al-Sabti (1986) revealed $2 n=$ 50 and NF $=84$, karyotype with a karyotype composed of 17 pairs of $\mathrm{m}$-sm and 8 pairs of st/a chromosomes, while Boron et al. (2009) identified $2 n=50$ and NF = 82, with a karyotype composed of 5 pairs of $m, 11$ pairs of sm, 5 pairs of st and 4 pairs of a chromosomes. Karyotype characteristics of $S$. cephalus in those studies are different from $S$. anatolicus. In addition, in the karyotypes of $S$. alburnoides, S. lucumonis, $S$. aradensis and $S$. torgalensis were determined chromosome structure as distinct from S. anatolicus (Table 2) (Gromicho and Collares-Pereira, 2004; Rossi et al., 2012; Nabais et al., 2013).

In S. cephalus, L. idus, and $L$. leuciscus, the heterochromatic blocks were identified in the pericentromeric regions of most chromosomes (Boron et al., 2009). Karasu Ayata (2020) and Unal and Gaffaroğlu (2016) found CH blocks in pericentromeric and distal part in chromosomes of S. carinus, S. fellowesii and S. seyhanensis. These studies are fairly similar to results obtained in $S$. anatolicus. While NORs are generally observed at the end of the short arms of st and sm chromosomes, they can sometimes be observed at the end of the long arms of st and sm chromosomes, on the arms of $\mathrm{m}$ and a chromosomes; between telomeres and centromeres, and adjacent to centromeres (Galetti et al., 1984). The present study supports the results of Galetti et al. (1984) in that NORs were localized on the short arms of sm chromosomes. 
Table 2. Cytogenetic data of some Squalius species.

\begin{tabular}{|c|c|c|c|c|}
\hline Species & $2 n$ & Chromosome morphology & NF & References \\
\hline S. carolitertii & 50 & $10-12 m+30-32 s m+8 s t / a$ & 92 & Collares-Pereira et al. (1998) \\
\hline S. pyrenaicus & 50 & $12 m+32 s m+6 s t / a$ & 94 & Collares-Pereira et al. (1998) \\
\hline S. pyrenaicus & 50 & $16 m+28 s m+6 a$ & - & Gromicho and Collares-Pereira (2004) \\
\hline S. alburnoides & 50 & $16 m+30 s m+4 s t / a$ & 96 & Gromicho and Collares-Pereira (2004) \\
\hline S. lucumonis & 50 & $16 m+26 s m+8 s t / a$ & - & Rossi et al. (2012) \\
\hline S. aradensis & 50 & $10 m+36 s m+4 s t / a$ & 96 & Nabais et al. (2013) \\
\hline S. torgalensis & 50 & $10 m+36 s m+4 s t / a$ & 96 & Nabais et al. (2013) \\
\hline S. seyhanensis & 50 & $16 m+28 s m+6 s t / a$ & 94 & Unal and Gaffaroğlu (2016) \\
\hline S. carinus & 50 & $24 m+20 s m+6 s t / a$ & 94 & Karasu Ayata (2020) \\
\hline S. fellowesii & 50 & $20 m+20 s m+10 s t / a$ & 90 & Karasu Ayata (2020) \\
\hline S. anatolicus & 50 & $14 m+26 s m+10 s t / a$ & 90 & Present study \\
\hline
\end{tabular}

Karasu Ayata (2020) and Unal and Gaffaroğlu (2016) reported that two NORs were on the short arms of sm chromosomes in S. carinus, S. fellowesii and S. seyhanensis but NORs were reported that on the long arms of second largest sm chromosomes in L. idus (Boron et al., 2009). Rossi et al. (2012) observed two heteromorphic in size NORs on the short arms of a medium-sized sm chromosome pair in $S$. lucumonis and this occurrence was explained that by FISH using the 45S rDNA probe. According to this study, it was evident that the $5 \mathrm{~S}$ signals were proximal and co-localized with the distal NORs and this character should be ancestral within the entire Leuciscinae lineage. The presence of NORs on the sm chromosome pair of $S$. anatolicus is in line with

\section{REFERENCES}

Al-Sabti, K. (1986). Karyotypes of Cyprinus carpio and Leuciscus cephalus. Cytobios, 47, 19-25.

Amemiya, C. T. \& Gold, J. R. (1990). Chromosomal NOR phenotypes of seven species of North American Cyprinidae, with comments on cytosystematic relationships of the Notropis volucellus species-group, Opsopoeodus emiliae, and the genus Pteronotropis. Copeia, 1, 68-78. DOI: $10.2307 / 1445823$

Aydogdu, A., Keskin, N., Erkakan, F. \& Innal, D. (2015). Occurrence of helminth parasites in the Turkish endemic fish, Squalius anatolicus (Cyprinidae). Bulletin of the European Association of Fish Pathologists, 35(5), 185-191.

Bianco, P. G., Aprea, G., Balletto, E., Capriglione, T., Fulgione, D. \& Odierna, G. (2004). The karyology of the cyprinid genera Scardinius and Rutilus in southern Europe. Ichthyological Research, 51(3), 274-278. DOI:10.1007/s10228-004-0221-y

Bogutskaya, N. G. (1997). Contribution to the knowledge of leuciscine fishes of Asia Minor. Part 2. An annotated check-list of leuciscine fishes (Leuciscinae, Cyprinidae) of Turkey with descriptions of a new species and two new subspecies. Mitteilungen aus dem Hamburgischen Zoologischen Museum und Institut, 94, 161-186.

Boron, A., Porycka, K., Ito, D., Abe, S. \& Kirtiklis, L. (2009). Comparative molecular cytogenetic analysis of three Leuciscus species (Pisces, Cyprinidae) using chromosome banding and FISH with rDNA. Genetica, 135(2), 199-207. DOI: 10.1007/s10709-008-9269-3

Collares-Pereira, M. J. (1992). In vivo direct chromosome preparation (protocol for air drying technique). In First International Workshop on Fish Cytogenetic Techniques 1992 (pp. 14-24). Paris, France: Museum Nat. Histoire Naturelle.
NOR phenotypes and size heteromorphism of NORs presented in these studies.

In conclusion, the karyotype having typically the largest st/a chromosome pair of $S$. anatolicus is characteristic of leuciscines in terms of the chromosome number and morphology, the distribution of $\mathrm{CH}$ and NOR phenotype. These findings support that consistency of karyotypes and chromosomal banding patterns in especially leuciscines. In addition, the presented cytotaxonomic characters should be scrutiny by molecular methods for further cytogenetic studies to understand evolutionary processes within the related leuciscid lineages.

Collares-Pereira, M. J., Propero, M. I., Bileu, R. I. \& Rodrigues, E. (1998). Leuciscus (Pisces, Cyprinidae) karyotypes: transect of Porteguese populations. Genetics and Molecular Biology, 21(1), 63-69. DOI: $10.1590 / S 1415-47571998000100011$

Çiçek, E., Sungur, S. \& Fricke, R. (2020). Freshwater lampreys and fishes of Turkey; a revised and updated annotated checklist. Zootaxa, 4809(2), 241-270. DOI: 10.11646/zootaxa.4809.2.2

Doadrio, I. \& Carmona, J. A. (1998). Genetic divergence in Greek populations of the genus Leuciscus and its evolutionary and biogeographical implications. Journal of Fish Biology, 53(3), 591-613. DOI: 10.1111/j.1095-8649.1998.tb01004.X

Freyhof, J. (2014). Squalius anatolicus. The IUCN Red List of Threatened Species 2014. Alıntılanma adresi: https://www.iucnredlist.org/species/60732/19007710 (11.03.2021).

Galetti, P. M., Foresti, F., Bertollo, L. A. C. \& Moreira, F. O. (1984). Characterization of eight species of Anostomidae (Cypriniformes) fish on the basis of the nucleolar organizing region. Caryologia, 37(4), 401-406. DOI: $10.1080 / 00087114.1984 .10797718$

Gromicho, M. \& Collares-Pereira, M. J. (2004). Polymorphism of major ribosomal gene chromosomal sites (NOR-phenotypes) in the hybridogenetic fish Squalius alburnoides complex (Cyprinidae) assessed through crossing experiments. Genetica, 122(3), 291-302. DOI:10.1007/s10709-004-1420-1

Howell, W. M. \& Black, D. A. (1980). Controlled silver-staining of nucleolus organizer regions with a protective colloidal developer: a 1-step method. Experientia, 36(8), 1014-1015. DOI: 10.1007/BF01953855 
Karasu Ayata, M. (2020). Comparative cytogenetics of two Squalius Bonaparte, 1837 species (Cypriniformes: Leuciscidae). Iranian Journal of Science and Technology, Transactions A: Science, 44(2), 355-360. DOI: 10.1007/s40995-020-00836-0

Levan, A., Fredga, K. \& Sandberg, A. A. (1964). Nomenclature for centromeric position on chromosomes. Hereditas, 52(2), 201-220. DOI:10.1111/j.1601-5223.1964.tb01953.x

Mazik, E. Y., Toktosunov, A. T. \& Gnidenko, S. M. (1986). Comparative karyology of dace (Leuciscus, Cypriniformes, Cyprinidae) from the northern Tien-Shan. Zoologicheskii Zhurnal, 65, 1350-1355.

Nabais, C., Rampin, M. \& Collares-Pereira, M. J. (2013). Comparative cytogenetics of two endangered leuciscine fish, Squalius aradensis and S. torgalensis (Teleostei, Cyprinidae), from the Iberian Peninsula. Comparative Cytogenetics, 7(1), 33-42 DOI: $10.3897 /$ CompCytogen.v7i1.4672

Özulug, M. \& Freyhof, J. (2011). Revision of the genus Squalius in Western and Central Anatolia, with description of four new species (Teleostei: Cyprinidae). Ichthyological Exploration of Freshwaters, 22(2), 107-148.

Pereira, C. S. A., Ráb, P. \& Collares-Pereira, M. J. (2013). Chromosomes of Iberian Leuciscinae (Cyprinidae) revisited: Evidence of genome restructuring in homoploid hybrids using dual-color FISH and CGH Cytogenetic and Genome Research, 141(2-3), 143-152. DOI:10.1159/000354582

Rab, P. \& Collares-Pereira, M. J. (1995). Chromosomes of European Cyprinid fishes (Cyprinidae, Cypriniformes): A review. Folia Zoologica, $44,193-214$.
Rossi, A. R., Milana, V., Hett, A. K. \& Tancioni, L. (2012). Molecular cytogenetic analysis of the Appenine endemic cyprinid fish Squalius lucumonis and three other Italian leuciscines using chromosome banding and FISH with rDNA probes. Genetica, 140(10), 469-476. DOI: 10.1007/s10709-012-9695-0

Stoumboudi, M. T., Kottelat, M. \& Barbieri, R. (2006). The fishes of the inland waters of Lesbos Island, Greece. Ichthyological Exploration of Freshwaters, 17(2), 129-146.

Sumner, A. T. (1972). A simple technique for demonstrating centromeric heterochromatin. Experimental Cell Research, 75, 304-306. DOI:10.1016/0014-4827(72)90558-7

Turan, D., YıImaz, B. T. \& Kaya, C. (2009). Squalius kottelati, a new cyprinid species (Teleostei: Cyprinidae) from Orontes River, Turkey. Zootaxa, 2270(1), 53-62. DOI: 10.11646/zootaxa.2270.1.3

Turan, D., Kottelat, M. \& Doğan, E. (2013). Two new species of Squalius, S. adanaensis and $S$. seyhanensis (Teleostei: Cyprinidae), from the Seyhan River in Turkey. Zootaxa, 3637(3), 308-324. DOI: 10.11646/zootaxa.3637.3.4

Unal, S. \& Gaffaroğlu, M. (2016). Karyology of six cyprinid fishes from Seyhan and Ceyhan rivers in Anatolia. Caryologia, 69(4), 362-369. DOI: $10.1080 / 00087114.2016 .1247328$

Zardoya, R. \& Doadrio, I. (1999). Molecular evidence on the evolutionary and biogeographical patterns of European cyprinids. Journal of Molecular Evolution, 49(2), 227-237.

DOI:10.1007/PL00006545 